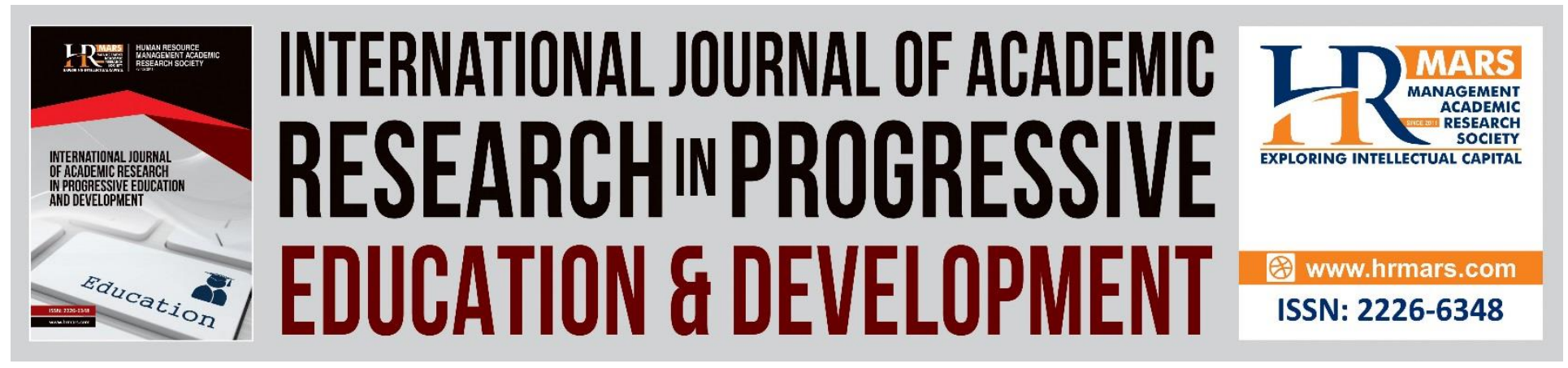

\title{
A Non-state University's Contribution to the Tertiary Education Landscape in Ghana
}

Alfred Kuranchie, Mavis Okyere, Ernest Larbi

To Link this Article: http://dx.doi.org/10.6007/IJARPED/v10-i1/8327

DOI:10.6007/IJARPED/v10-i1/8327

Received: 13 December 2020, Revised: 06 January 2021, Accepted: 26 January 2021

Published Online: 17 February 2021

In-Text Citation: (Kuranchie et al., 2021)

To Cite this Article: Kuranchie, A., Okyere, M., \& Larbi, E. (2021). A Non-state University's Contribution to the Tertiary Education Landscape in Ghana. International Journal of Academic Research in Progressive Education and Development, 10(1), 99-113.

Copyright: (C) 2021 The Author(s)

Published by Human Resource Management Academic Research Society (www.hrmars.com)

This article is published under the Creative Commons Attribution (CC BY 4.0) license. Anyone may reproduce, distribute, translate and create derivative works of this article (for both commercial and non-commercial purposes), subject to full attribution to the original publication and authors. The full terms of this license may be seen at: $\underline{\text { http://creativecommons.org/licences/by/4.0/legalcode }}$

Vol. 10(1) 2021, Pg. 99 - 113

http://hrmars.com/index.php/pages/detail/IJARPED JOURNAL HOMEPAGE

Full Terms $\&$ Conditions of access and use can be found at http://hrmars.com/index.php/pages/detail/publication-ethics 


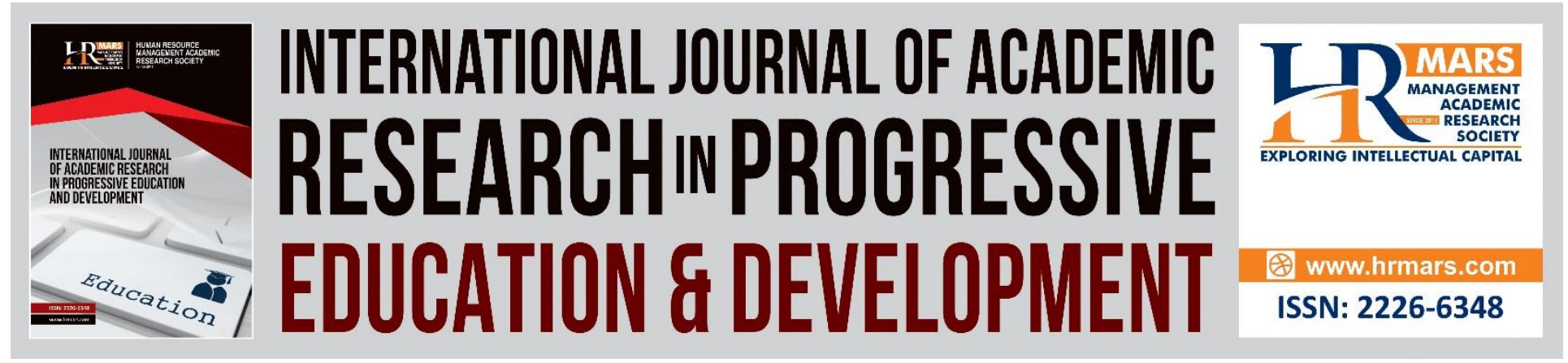

\title{
A Non-state University's Contribution to the Tertiary Education Landscape in Ghana
}

\author{
Alfred Kuranchie \\ (PhD), Department of Social Studies Education, University of Education, Winneba, Ghana. \\ Email: kuranchiealf@yahoo.com \\ Mavis Okyere \\ (PhD Candidate), Department of Mathematics and Science Education, Catholic University \\ College of Ghana, Sunyani, Ghana. \\ Email: mavisokyere020@gmail.com \\ Ernest Larbi \\ (PhD Candidate), Department of Mathematics Education, AAA University of Entrepreneurship \\ and Skills, Kumasi, Ghana. \\ Email: ertlarbi@gmail.com
}

\begin{abstract}
The relevance of university education to human capital formation and socio-economic development of nations is not in doubt. Hence, both state and non-state actors are permitted to offer university education to achieve that end in most jurisdictions. In Ghana, the monopolistic power of the state in providing university education paved way to private sector participation ostensibly to widening access to many qualified prospective students who seek admission. The private universities now outnumber the public ones and the central question is "how meaningfully is the private sector aiding the state in providing university education in the country"? The study set out to find answers to the question using one of the premier private universities as a case. Primary and secondary data were gathered via interview and content analysis to provide evidence of the university's contribution to higher education. It was discovered that the institution has made some germane contributions in the areas of access, programme and community service to broaden university education landscape in the country. The paper concludes with recommendations that could aid to address the challenges identified to enable the private university to, probably, double its contributions to university education. Keywords: University Education, Private Sector, Public Sector, Contributions and Challenges.
\end{abstract}




\section{Introduction}

In the history of man, education has arguably been the single most significant phenomenon that has undoubtedly been reckoned as an elixir and panacea to human's predicaments. Since its conception and introduction centuries ago, education has been embraced by individuals, families and states due to its ability to equip people with the knowledge, skills and values that are a pre-requisite for individuals and states' progress and development. Education is the process of the intellectual development of individuals through which their potentials are unlocked, sharpened and developed, and the culture of the people is transmitted to the following generations (Niazi \& Mace, 2006). Through education, individuals are given opportunity to acquire knowledge and develop skills, attitudes and values necessary to develop their capacities for work (Bandele \& Faremi, 2013). World Bank (2002) asserts that the benefits derived from education have made it a fundamental human right for everyone and for that matter most countries are endeavouring to provide education to all their people.

Education plays pivotal roles in the life of individuals; it enables individuals to understand their immediate environment in order to manage their life, enhances their ability to study the world around them and develop strong bases for rationalising and reasoning skills in nation building. It also helps in economic and social transformation. In view of these, education for social change and development has been a major theme which has influenced many educational developments for the last century (Elliot, Fourali \& Issler, 2010). Although the basic and secondary levels of education are essential for individual and national development, the tertiary level is par excellence and it is considered primus inter parry. Hence, the focus has now shifted to higher education as it is deemed to yield more social returns. The quantum and quality of competence imparted by universities to their patrons is monumental. Consequently, there has been a wide expansion of higher education globally. Over the last 800 years, university education has grown tremendously and enrolment has transcended hundred million mark and that if universities were a nation that nation would rank among the world's biggest nations just after Mexico (UNESCO, 2008).

Tertiary education includes post-secondary institutions such as universities, polytechnics and colleges that offer broad range of learning and training to their clienteles. These institutions prepare students for different career opportunities and in the production of the higher order capacity necessary for nation development. Higher educational institutions are governed by laws or some accreditation processes to enable them execute such functions as teaching, research and community services in tandem with their mission statements and goals. Tertiary institutions are meant to provide advance and/or professional instructions and conduct research to generate knowledge, disseminate information and provide community services (Amenyah, 2009).

The development of every nation lies heavily on provision of education to its members. Higher education plays very essential role in human, social, political and economic stability and advancement of countries. It develops human capital for the nation's workforce (Escrigas, 2008). Higher education centres are therefore repositories of knowledge hence they are the key to sustainable national development, peace and stability within and among nations. Universities play a major role in the enhancement of human capital necessary for the advancement of nations. They offer wide range of academic and professional programmes to build knowledge, skills, attitudes and ethics that construct the human capital for nations. They provide services 
that build social capital necessary for healthy civil societies, cohesive social cultures and democratic political systems. Based on the foregoing, higher education needs to be made accessible to all categories of people, and to both men and women as they are all needed for nation building (World Bank, 2002).

Higher education also confers essential public goods that are critical to progress and poverty reduction. This level of education usually leads to higher earnings and economic and social mobility. Most governments, therefore, invest in human resources as they believe that their people are the best resource (Rena, 2006). There cannot be any meaningful productive development of physical capital if human capital is ignored, and that developing human capital through education is the optimal investment of any conscious country aimed at competing in the global economy (Kouassi, 2013). Human resource provides very significant input, which serves as basis for wealth creation of a nation. Educated elites are agents of production who accrue capitals, exploit natural resources, build and develop social, political and economic organizations that plan and implement national development programmes. Consequently, a nation which is unable to develop its human capital for utilisation in the nation's building cannot develop anything else (Utaka, 2003). The knowledge base of a country is its ability to generate and utilise new ideas and skills and to transform them into economic development (Haggins \& Izushi, 2007), Ghana has developed keen interest in tertiary education due to its capacity to produce adequate skilled human resources for socio-economic development and industrial transformation of the country (Nsia-Gyabaa, 2011).

Areas in which universities contribute to industrial transformation as (i) education and training; (ii) adding to the stock of knowledge via publications in the technical literatures, patent, software and hardware examples; (iii) increasing the local capacity for scientific and technological problem solving; and (iv) providing space for open-ended conversation about industrial development pathways and new technological and market opportunities (Lester \& Liore, 2004). These functions of universities underscore the view that if communities desire to improve the quality of life of their citizens they ought to foster partnership with higher education (Holland \& Gelmon, 1998). Universities play essential roles in economic and social development of nations (Gary, 1999) and contribute immensely to sustainable development of nations and the global world.

Universities are also very influential in promoting other sectors of the economy. This is because they produce competent and qualified staff to feed them to achieve their organisational goals. Different types and levels of human resource are produced by the universities to service the various sectors of the economy. The numerous roles played by higher education have necessitated nations to focus on investing in it (Machumu \& Kissanga, 2014).

\section{Private Sector Participation in University Education}

Private sector education is provided by non-state actors. The form of ownership of private educational institutions varies from individuals through families, private companies to religious bodies (Chimombo, Dzimadzi, Kunje \& Lewin, 2005). The private sector is permitted to provide education at all levels with varying degrees of control. In Ghana, as in some other countries, private universities are first affiliated with well-established ones before accreditation is granted. This arrangement leads to collaboration between the mentoring and mentored institutions and 
the working relationship is usually in terms of curriculum, instruction and assessment. The mentoring university provides instructional supervision, quality and standard control. The mentorship also includes the award of the mentoring universities' certificates, diplomas and degrees to the qualified students of the mentored universities (Kuranchie, 2013).

In Ghana, the National Accreditation Board (NAB) is responsible for the accreditation of both public and private tertiary institutions with respect to programme contents and standards, staffing, admissions, infrastructure and other essential conditions that enhance quality teaching and learning. The National Council for Tertiary Education (NCTE), an agency of the Ministry of Education (MoE), also provides consultation on education policy for institutions and reports to government on the conditions of higher education in the country. Consequently, NAB, NCTE and the mentoring institutions ensure that high standards are maintained by the private universities in order to offer value for money services to their clienteles (Kuranchie, 2013). During the period of mentorship, the private universities continue to function independent of state direct financial support (Mabizela, 2007). The arrangement is that private universities are granted autonomy after ten years of operation and subject to meeting other certain vital and essential conditions.

There has been a rapid evolution and expansion of private institutions of higher learning in many countries. Due to increased private participation in higher education across the world, there was an increase in worldwide student enrolment from 13 million in 1960 to 82 million in 1995 and to 137 million in 2005 (UNESCO, 1998, UNESCO, 2007). This ascendency of students' enrolment in universities is not different in Ghana. In the 2003/2004 academic year, the total number of students enrolled in various programmes in both public and private universities was 84,078 and $10 \%$ of this figure constituted those enrolled in private universities. During the $2014 / 2015$ academic year, students enrolled in both public and private institutions in the country was 319, 659 with over 26\% intake in private universities (Amponsah, \& Onuoha, 2013). These figures connote that private universities are also a force to reckon with when it comes provision of university education in Ghana.

\section{Problem Statement}

The effort to provide higher education has been due to high social demand which could be traced to the colonial days. In the pre-independence era, only a few most deserving aspiring students were awarded scholarships to pursue higher education abroad due to non-availability of higher education centres in the country (Amponsah \& Onuoha, 2013). The 1948 Education Ordinance saw the establishment of the University College of Gold Coast (now University of Ghana) by the British colonial administration to offer limited programmes of study. With passage of time, funding of higher education which was a responsibility of the government became a big challenge. As a result, in 1987, a University Rationalisation Committee (URC) was constituted to develop a framework for reforming management, academic structure and funding of tertiary education in Ghana. Based on the committee's report, the government issued a White Paper in 1991 on the reforms in the tertiary education system. One of the tertiary education policy objectives was significant expansion of the tertiary education system as a whole to meet the demands of school leavers and those who were previously denied it (Utaka, 2003).

In the 1990's, when the products of the new educational system (senior secondary school) passed out in the successive years, the social demand for higher education became rife and the 
most feasible way to weather the storm was to allow private sector participation in the provision of tertiary education. The state was facing the challenge of funding tertiary education and there were limited facilities in the few existing public universities, which could not meet the high demands for university education. The state funded universities' inability to absorb the qualified students was exacerbated by the almost one-year prolonged strike by university staff nationwide in 1994/95 academic year. No admissions were done in the entire academic year by the existing universities. When the universities eventually resumed work, the demand for admission increased astronomically to a point where the need for private participation became so urgent and compelling that it could no longer be denied. As a result, there was a decision to bring on board private sector participation in higher education, increase the number of public universities and introduce cost sharing (Kubi, 2005). Since then, the National Accreditation Board (NAB) has been permitting private universities to offer tertiary education to qualified students who are desirous of acquiring advance knowledge and skills, and overall personal development. The private sector participation has also enabled the state to channel some public resources to other equally important ventures to cater for the disadvantaged, the poor and needy in the society (Education Reforms in Ghana, 2002).

The private sector involvement in the provision of tertiary education was also due to its capacity to widening access to more applicants to achieve the Education for All (EFA), Millennium Development Goals (MDGs), now Sustainable Development Goals (SDGs) on education agendas. Article 25 (2) of the 1992 constitution also gave impetus to the entry of the private sector in university education provisioning in the Ghanaian economy. The provision in the constitution states, inter alia, "that individuals and groups can establish private schools without state contribution of any sort: every person shall have the right, at his/her own expense, to set up and maintain a private school or schools at all levels and of such categories and in accordance with such conditions as may be provided by law" (Ministry of Education/Ghana Education Service (MoE/GES, 2001). Another catalyst to private sector involvement in university education was the fact that there was the effort to increase participation in higher education across the world (UNESCO, 2007). For instance, countries such as Kenya, Senegal, Uganda, and Benin amended their educational policies to allow private participation in higher education in the 1990's (Vargese, 2004). Ghana could not have stayed aloof to the desire of expanding access to university education globally.

Consequently, in the last two decades, the country has experienced rapid establishment of private universities, which is aptly described as private university boom in Ghana (Kuranchie, 2013). The country has seen substantial growth in the private provision of university education for well over two decades, some of which have gained autonomy and are operating as fully fledged universities. Yet not much has been done to unfurl the extent to which they are faring in achieving their mandates. The research was executed to achieve that end and to contribute to knowledge, policy and practice.

\section{Research Objectives}

The study focused on the following:

- To unravel the university's contributions to the tertiary trajectory of education.

- To ascertain the challenges the university encounters while pursuing its mandate. 
INTERNATIONAL JOURNAL OF ACADEMIC RESEARCH IN PROGRESSIVE EDUCATION AND

DEVELOPMENT

Vol. 10, No. 1, 2021, E-ISSN: 2226-6348 @ 2021 HRMARS

\section{Method and Materials \\ Study Design}

The study was qualitative in nature. Exploratory design was employed to unravel the contributions of the university college to the university trajectory of education. This design enabled the researchers to explore data from various segments of the university to achieve the study objectives.

\section{Population and Sample}

In view of the nature and aims of the research, key informants who play very vital roles in the activities of the institution were purposively chosen to provide data. Twelve (12) officers who were custodians of some vital information and those who played influential roles in the groups that provided community services were relied on for the research data. The key informants who were very helpful to the researchers in getting the data are two (2) assistant registrars; four (4) academic staff; two (2) non-academic staff; and four (4) student team leaders.

\section{Data Type and Source}

Both primary and secondary data were gathered to achieve the study objectives. Semistructured interviews were conducted with the officers at separate times for the primary data. Mostly, the interviews were done at the interviewees' offices and at their convenience. Also, some data were gathered from the university college's newsletter, vice-chancellor's annual reports and basic statistics. The content analysis of the documents was done to get secondary data to confirm and expand the primary data.

\section{Results of the Study}

The results of the study are presented in themes and sub-themes which emerged from the data analysis. The major themes are expansion of access, new programmes, community service and challenges. The designations of the participants are as follow: Assistant Registrars AR1, AR2; Academic Staff - AS1, AS2, AS3, AS4; Non-academic staff - NAS1, NAS2; and Student team leaders - STL1, STL2, STL3, STL4.

\section{Expansion of Access to University Education}

It emerged from the interviews that the university college is contributing so much to widening access to university education. The university has students from within and outside the country who are pursuing various certificate, diploma and degree programmes.

\section{Double Admissions}

The institution has since its establishment been offering admission twice in every academic year (August/September and January/February), which has been of immense help to qualified students to pursue varied programmes. In this situation, students who miss the main August/September admission do not have to stay home for the next academic year. Those students have the opportunity to enrol in the January/February admission window.

An interviewee posited the university college is the first to start January admission in the country. 
After initiating and running two admissions in an academic year, some other private universities have emulated it (AR2).

The university also runs two streams of lectures on week days and weekends. The weekend stream especially provides opportunity to the working class to pursue tertiary education while maintaining their jobs.

An interviewee intimated

there was even a third stream, night school, which has been stopped for

some time now. Currently, the week day and weekend streams are being

run to give opportunities to both the working and non-working classes to have advance education (AR1).

He added that

the academic programmes run on regular days are the same as those of

the weekends. Hence, the quality of, tuition and certificates for both the

regular and weekend programmes are the same (AR1).

An interviewee said that

that is why no one should think that only weak students who fail to gain admission into the traditional universities go to private universities as there are more cogent reasons for choosing to study in a private university. Now, the dynamics have changed and people need to be abreast of the changing world and its ramifications with respect to deciding where to study (AS1).

Another interviewee said that

many are workers who find it extremely difficult to secure study leave to pursue further education. Besides, many people may not have their positions back after going on study leave hence, they would want to concurrently pursue higher education while working (AS3).

\section{Pre-tertiary Education Classes}

The interviewees also disclosed that the university has been running pre-university classes for Senior High School (SHS) graduates who are unable to make it on the first sitting. The lecturers who have had years of teaching and examining experience prepare the students to write the West Africa Senior Secondary Certificate Examination (WASSCE), most of whom pass very well.

A participant reiterated

The students who patronize the pre-university classes after making

the grades have the right to opt to pursue their bachelor degree programmes in this university or anywhere (AS2).

\section{Collaborations}

The university has been having collaboration with some institutions and bodies such as the African Sister Education Collaboration (ASEC), which has yielded high dividends for both partners. A lot of reverend sisters from different countries have their studies in the university. Two interviewees indicated that via the collaboration, for some years now, students from different countries 
especially in the West Africa sub-region have been enrolling in various academic programmes in the university to upgrade themselves (AR1, AS3).

\section{New Programmes to Widen Students' Choice}

The interviewees indicated that the university college is running programmes that the traditional universities are also offering. However, the university college runs some cutting-edge programmes, which were first introduced in the country by the institution. The institution has fashioned numerous academic programmes at the certificate, diploma, undergraduate and postgraduate levels. The programmes are run in five faculties namely, Religion and Social Sciences (RSS); Education (Edu); Information Communication and Sciences Technology (ICST); Economics and Business Administration EBA; and Health and Allied Sciences (HAS).

An interviewee said

the university college was the first to run Public Health and Allied

Sciences programme at the undergraduate level in the country. Two public

universities were however offering it at the postgraduate levels (AR2).

He added that

the university college was the first private university in the country to

run Education programme at the university level in the jurisdiction.

It is also the first private university to run Postgraduate Diploma in

Education (PGDE) on the regular stream. All other institutions run

The PGDE on sandwich basis (AS3).

\section{Performance of Alumni}

\section{Excellence at the world of work}

The interviewees reported that the outcomes of various tracer studies that have been conducted over the years pointed to the direction that former students of the university are doing very well in the world of work. The products of the university are employed in various sectors of the economy some of whom are heading some organisations of high repute.

Two interviewees intimated that

outcomes of tracer studies show that some of alumni are excelling as

employees and self-employees in various areas of endeavour. Some of

them have established their own businesses and are making it big (NAS1, AS2).

An interviewee said

our graduates easily gain employments. For instance, the Faculty of Education products are employed in the education sector and are faring very well. Both private and public junior and senior high schools in the country readily absorb the graduates from our programmes into their folds (NAS2).

An interviewee indicated that in view of the high quality of our education programme, a lot of applications is received from non-professional graduate teachers to pursue postgraduate diploma in education. It is the flagship programme in the Faculty. (NAS1).

Two interviewees asserted that 
since majority of the students who are admitted into the university college are already in employment, unemployment is not a headache for the university. When the students on study leave complete their programmes, they are upgraded (NAS1, NAS2).

\section{Academic Progression of alumni}

It was revealed that a good number of the past students had pursued and some were also pursuing various programmes at the master's and PhD levels in various universities in and outside the country.

An interviewee said many past students have pursued further studies some of whom are lecturers in this university and others. A number of them are also on their terminal degree programmes, who are faring well (AR1).

\section{Contributions to the Community}

The interviewees revealed that the university college executes a number of services to its publics. Some faculties are performing very well on this score, which have been manifested locally, nationally and internationally.

\section{Faculty of Education's Community Services}

Staff of the Faculty of Education offer counselling services to basic and senior high school students and teachers in the Brong Ahafo region.

An interviewee said

The team organises seminars for students on various issues such as

sex education, homosexuality, vocational guidance, time management, examination and anxiety. The staff also organise workshops and seminars on instructional techniques and classroom testing for both public and private basic school teachers (AS2).

The staff have also organised seminars on data analysis and interpretations to interested people in the university community.

Two interviewees said

on a number of occasions, the staff have organised such programmes in some districts in the Brong Ahafo region (AS2, STL1).

The Faculty has also organised symposia on political tolerance for senior high students in the region prior to the 2012 and 2016 national elections respectively. These programmes were well patronised and it is believed to have immensely contributed to the peaceful exercise in the two occasions.

One interview said, on two occasions, the staff organised education on voting and electoral processes for students in second cycle institutions in the region. On both occasions, the speakers were drawn from the National Commission for Civic Education (NCCE), Regional electoral commission office and the university to provide professional guidance to the youth to ensure political tolerance and 
INTERNATIONAL JOURNAL OF ACADEMIC RESEARCH IN PROGRESSIVE EDUCATION AND

DEVELOPMENT

Vol. 10, No. 1, 2021, E-ISSN: 2226-6348 @ 2021 HRMARS

peaceful elections (AS1).

\section{Faculty of Religions and Social Science's Community Service}

The university college also has a Marian Conflict Resolution Centre (MCRC), which has been organising workshops on Alternative Dispute Resolution (ADR) for various participants. The then Chief Justice of the Republic of Ghana, her ladyship, Mrs Georgina Theodora Woode, commissioned the inauguration of the centre in 2011. The first workshop was held between $1^{\text {st }}$ and $5^{\text {th }}$ August, 2011 which attracted patrons from all walks of life.

Two interviewees respectively said that

the centre utilises local and international lecturers and practising lawyers

of high repute to facilitate the workshops (AS2).

The facilitators of the first workshop, for instance, were from the Legal Aid Ghana, Fordham University, and St John's University School of Law (AS3).

In 2016, the following workshops were organised by the centre: Mediation training for Public Utilities and Regulatory Commission (PURC); Skills development training for students in Negotiation and Mediation; Alternative Dispute Resolution (ADR); and Promotion and Protection of Human Rights.

An interviewee said

the ADR staff of the university have also been helping in settling disputes

in the adjudicating centres mostly in the region. Their involvement in settling

out of court disputes has been phenomenal and recognised in the region. (AS3).

The Religious Studies Faculty also organised a short course on Protection of minors in June and July 2016 to augment its community service responsibilities.

An interviewee indicated that

the programme was participated by all kinds of staff whose work required knowledge from that field (AS3).

\section{Faculty of Economics and Business Administration's Community Service}

Another flagship community service programme of the university is Students in Free Enterprise (SIFE) now ENACTUS under management of some staff of the Faculty of Economics and Business Administration. This student group is in tertiary institutions worldwide and undertakes entrepreneurial activities to help the needy in the society. It aims at bringing today and tomorrow leaders to gather to create a more sustainable world through the power of business. The groups compete at national and international levels. As part of it activities, SIFE/ENACTUS CUCG undertakes income generating ventures and provide training to rural dwellers to have employable skills and also equip them with resources to start their own businesses.

Some interviewees disclosed that

SIFE/ENACTUS CUCG has won the competition twice and represented

Ghana at SIFE World Cup 2012 in Washington DC, USA and SIFE World

Cup 2013 in Mexico respectively. (AR1, AS 2, STL3, STL4).

In 2017, the group won the Duapa challenge competition competed for by public

and private universities in the country (AS2, STL2). 
INTERNATIONAL JOURNAL OF ACADEMIC RESEARCH IN PROGRESSIVE EDUCATION AND

DEVELOPMENT

Vol. 10, No. 1, 2021, E-ISSN: 2226-6348 @ 2021 HRMARS

\section{Challenges Encountered in Pursuing its Mandate}

The running of the university has not been without challenges. The major challenges emerged from the interviews with the participants are as follow:

\section{Mentorship}

The first challenge has to do with the mentorship. The interviewees lamented about the high charges by the mentoring universities, which are in dollars.

An interviewee indicated that

considering the free fall of the value of Ghana cedis, converting it to

dollars is a huge challenge to the university. The high charges by the

mentoring institutions are a drain to private universities (AR2).

Another challenge is the inability of the mentored university to run programmes that the mentoring institutions are not offering. This arises due to the mentoring university's inability to provide programme supervision. This situation stifles innovativeness in fashioning cutting-edge programmes to attract more applicants.

Two interviewees asserted,

offering the same programmes as our mentoring universities is not helping us as most applicants would want to opt for state funded institutions due to their low fees charged. Because they are state funded, public universities' fees are relatively low and that has the potency to attract more applicants (AS2, AS3).

A subtle but a serious challenge is the parent-child relationship that seems to characterise the mentorship arrangement. It is apparent that the mentoring universities' views are almost always imposed on the mentored institutions. The mentored university has little inputs into decision making in the arrangement.

An interviewee lamented,

it is as though every staff in public universities is academically superior

to every staff in private ones. And if you have a dissenting view, it becomes

your word against mine (AS4).

Further, mentoring institutions have mounted the same programmes that the University College is running in the vicinity, which is rendering staff of the mentored university almost jobless.

An interviewee asserted they have taken our potential students and if that intensifies they may take us out of operation. Our faith is in limbo (AS3).

\section{Inadequate State's support}

Another challenge the university encounters is inadequate support from the government and development partners, both local and international. The private university does not receive the kind of assistance that the state ones do enjoy from development partners.

An interviewee bemoaned

The lack of government recognition and appreciation that the private universities are helping to produce highly qualified human resource for the development of the country and the need to them is worrying. Not only does the state fail to support us but also development partners (AS1). 
INTERNATIONAL JOURNAL OF ACADEMIC RESEARCH IN PROGRESSIVE EDUCATION AND

DEVELOPMENT

Vol. 10, No. 1, 2021, E-ISSN: 2226-6348 @ 2021 HRMARS

\section{Public Perception of Private Universities}

Generally, the public perception about private institutions is not favourable. There is negative perception about students and products of private universities contrary to the reality on the ground. Many are people who belief that students who attend private universities are not up to the scratch, which discourage some suitable applicants to apply for admission.

Two interviewees indicated that

the negative perception of private universities permeates into and reflects

in organisations' reluctance to accept private university students for

attachments and internships (AR2, AS3).

\section{Secondary Data}

Data generated from the Vice-Chancellor's Reports and Basic Statistics of various congregations and CUCG Newsletters confirm the primary data from the interviews. The secondary data generated from the aforementioned documentary sources confirm that the faculties organise various activities for students and people in the region. Again, the secondary data depict evidences of breakthroughs of some alumni in the academia and the world of work. For instance, the July 2012 edition of the CUCG Newsletter contains SIFE 2012 award, the Chief Justice's speech during inauguration of the Alternative Dispute Resolution (ADR) Centre. The data from the secondary sources corroborated the interview data that the university is faring very well with its mandate.

\section{Conclusion and Recommendations}

Often times, private universities are perceived with a kind of lens without critically examining what they have brought to the table. The study was motivated by the fact that the only way to tone down the biases and stereotypes regarding private universities was to unearth the realities on the ground. This is a potent way to understanding the activities of private universities in the country. The exploratory study has unveiled that the institution has choked a great deal of achievements. The university college is tremendously aiding in training citizens to promote the social, economic, political and technological advancement of the nation. Its varied academic programmes are aiding to augment the graduate population in the various sectors of the economy. The university is making phenomenal and episodic contributions to the tertiary education landscape considering its in-roads in the local, national and international spheres. The institution's impact transcends national frontiers and can be concluded that it is really achieving its mandate.

Considering the achievements of the university for the relatively few years that it has been in existence, the notion that private universities are not doing well needs to be discarded by the general public. They rather need to be encouraged and supported by relevant bodies by amending their policies, structures and funding arrangements to encapsulate private universities to help immensely provide high quality education to the citizenry. The government and development partners need to rethink and improve their support for private universities to enable them help achieve sustainable development goals on education nationally and globally. Tax exemptions and tax holidays, for instance, could be extended to private universities to relieve and afford them some leverage to execute their functions. Direct financial support, and 
infrastructural and material support from the state and development partners as it pertains in some countries would not be out of place as it would immensely enhance private universities' capability to provide top notch higher education for the country's progress.

\section{Contributions of the Study}

The research is an exploratory one which has unveiled the contributions of a private university to the tertiary education landscape in Ghana. It is therefore a contribution to literature on the phenomena studied. There is little information on this subject in existing literature, so this effort could trigger other researchers' interest to pay much attention to this subject. The study also makes a contextual contribution. Via this study, the private sector contributions to tertiary education development in Ghana have unfolded. This signals to the world-wide education community the impeccable role that the private sector is performing in making higher education accessible and relevant to those capable of pursuing education at that echelon in a developing country, Ghana.

Further, studying the phenomena from a qualitative point of view afforded participants the opportunity to freely and deeply express their views relative to the issues embedded in the research problem. That stride has provided a significant contribution of the qualitative methodology to the phenomena studied.

\section{References}

Amenyah, A. M. (2009). Higher education in Ghana. http://www.ghanaweb.com.

Amponsah, E. B., \& Onuoha, L. N. (2013). The performance and challenges of private. universities in Ghana and Nigeria'. International Journal of Business and Social Science, $4(5), 256-263$.

Bandele, S. O., \& Faremi, Y. A. (2013). Early childhood education: Implications for sustainable national development. In M. B. Fabunmi (Ed.), Explorations of Education. Ibadan: His Lineage Publishing House.

Chimombo, J., Dzimadzi, C., Kunje, D., \& Lewin, K. (2005). The development of private sector providers of educational services in Malawi: Panacea or problem? Zomba. Malawi: CERT.

Education Reforms in Ghana. (2002). Report of the Education Reform Review Committee in Ghana, Accra: Adwinsa Publications Ltd.

Elliot, G., Fourali, C., \& Issler, S. (2010). Education and social change: Connecting local and global perspectives. London: Continuum.

Escrigas, R. (2008). "Forward" in GUNI Higher Education in the World 3. London: Palgrace McMillan.

Gary, H. (1999). Universities and the creation of wealth. (ed.). Buckingham: Open University Press.

Holland, B. A., \& Gelmon, S. B. (1998). The state of the 'engaged campus': What have we learned about building and sustaining university-community partnerships. AAHE Bulletin, 3-6.

Huggins, R., \& Izushi, H. (2007). Competing for knowledge: creating, connecting and growing. London: Routledge.

Kouassi, S. (2013). Towards Education for All in 2015: An analysis for monitoring progress 
of the education system of Cote D'ivoire. In M. B. Fabunmi (ed.), Explorations of Education. Ibadan: His Lineage Publishing House.

Kubi, A. (2005). Funding tertiary education in Ghana. http://www.ghanaweb.com/fundingtertiary-edu-Ghana.

Kuranchie, A. (2013). Children and wards of low-income class and access to university Education. Academic Journal of Interdisciplinary Studies, 2(2), 19-26.

Lester, R. K., \& Piore, M. (2004). Innovation and missing dimension. Cambridge: MIT Press.

Mabizela, M. (2007). Private surge amid public dominance in higher education: The African perspective. Council for Development of Social Science Research in Africa, 5(2), 15-38.

Machumu, H. J., \& Kissanga, S. H. (2014). Quality assurance practices in higher education institutions: Lesson from Africa

Ministry of Education/Ghana Education Service (MoE/GES) (2001). Report of the study on the constitutional and legal framework for the right to pre-tertiary education. Accra: Ministry of Education.

Niazi, H. K., Mace, J. (2006). The contribution of the private sector to higher education in Pakistan with particular reference to efficiency and equity. Bulletin of Education and Research, 28(2), $17-42$.

Nsiah-Gyabaah, K. (2011). The increasing demand for tertiary education in Ghana and female participation. Journal of Polytechnics in Ghana, 5(1), 49-68.

Rena, R. (2006). Education and human resources development in post-independent Eritrea: An exploratory note'. International Journal of Education and Development using Information and Communication Technology, 2(4), $67-81$.

Varghese, N. V. (2004). Private higher education in Africa. Paris: UNESCO.

Utaka, G. (2003). The emergence of private university education and the value of quality assurance in Ghana: The role of National Accreditation Board. httpwww.cardinalscholarbus.edu.

UNESCO. (1998). World declaration on higher education for the 21st century: Vision and Action. Paris: UNESCO

UNESCO. (2007), Global education digest: Comparing education statistics across the world. Retrieved: http//stat.uis.unesco.org/unesco.21/11/2016.

UNESCO. (2008) Tertiary education for the knowledge society. UNESCO: IIEP. World Bank. (2002). Constructing knowledge societies: New challenges for tertiary education. Washington, D C: World Bank. 